Riwayat Artikel: Diterima 10 Maret 2017; Direvisi 17 Juli 2017; Disetujui 18 Juli 2017; dan Dipublikasikan 26 Juli 2017

\title{
ANALISIS PENERAPAN E-GOVERNMENT DAN PERUBAHAN INTERAKSI SOSIAL SETELAH MEDIATISASI DI DESA KARANG BAJO, LOMBOK
}

\section{ANALYSIS OF E-GOVERNMENT IMPLEMENTATION AND CHANGES IN SOCIAL INTERACTION AFTER MEDIATIZATION IN KARANG BAJO VILLAGE, LOMBOK}

\author{
Wulan Purnama Sari \\ (wulanp@ fikom.untar.ac.id) \\ (Fakultas Ilmu Komunikasi, Universitas Tarumanagara)
}

\begin{abstract}
Abstrak
Era digital di Indonesia, tidak hanya membawa perubahan bagi orang-orang yang berada di daerah perkotaan, tetapi juga di daerah pedesaan yang belum memiliki akses memadai dalam hal sumber daya. Sebagai salah satu contohnya adalah sebuah desa di provinsi Lombok yang bernama Desa Karang Bajo. Desa Karang Bajo ini kemudian menerapkan pemerintahannya dengan memanfaatkan teknologi dan new media, dengan kata lain Desa Karang Bajo ini telah menerapkan sistem E-Government. Hal ini sejalan dengan konsep mediatiasi yang dapat diartikan sebagai konsep paling utama untuk memahami pentingnya media terhadap budaya dan masyarakat. Penelitian dilakukan dengan menggunakan pendekatan kualitatif dan metode studi kasus. Hasil yang diperoleh melalui penelitian ini E-Government yang diterapkan di desa Karang Bajo masih berada dalam tahap billboards dengan dasar tujuan utama adalah adanya UU No. 6 Tahun 2014 tentang sistem EGovernment. Hadirnya E-Government tidak membawa perubahan dalam interaksi sosial masyarakat.
\end{abstract}

Kata Kunci: E-Government, Mediatisasi, New Media

\section{Abstract}

In Indonesia, the digital era is not only brings difference for people residing in urban areas, but also in rural areas that do not have adequate access in terms of resources. As one example is a village in the province of Lombok named Karang Bajo. Karang Bajo village apply it's government with the use of technology and new media, in other words Karang Bajo Village has introduced a system of E-Government. This is in line with the concept mediatization which can be interpreted as the most important concepts to understand the importance of the media on culture and society. The study was conducted using a qualitative approach and case study method. The results from this research is E-Government applied in Karang Bajo village is still in the billboards stage with primaly puspose because constitution UU No. 6 (2014). The presence of E-Government didn't bring any changes in society's social interaction.

Keywords: E-Government, Mediatization, New Media

\section{Pendahuluan}

Era digital yang ditandai dengan hadirnya internet telah membawa banyak perubahan dalam kehidupan manusia. Setiap aspek dalam kehidupan manusia, kini berkaitan dengan penggunaan teknologi dan internet didalamnya. Salah satu aspek tersebut adalah komunikasi, dimana komunikasi dahulu lebih banyak dilakukan secara langsung, kini di era digital komunikasi mulai lebih mengarah kepada komunikasi tidak langsung.Dua individu tidak perlu lagi untuk bertatap muka secara langsung dan melakukan komunikasi, cukup dengan ponsel, email, messanger, dan lain-lain, maka dua orang yang terpisah jarah dapat tetap berhubungan dan berkomunikasi.

Wynants \& Cornelis (2005: 13) mengemukakan bahwa Internet membuka sebuah dunia baru yang penuh keterbukaan, hal apapun dapat dimasukkan ke dalam internet dan siapapun bebas mengaksesnya tanpa perlu mengeluarkan biaya tambahan atau dibatasi oleh hak 
cipta dan hak paten.Internet bahkan dianggap sebagai sebuah bentuk media baru yang akan menggantikan media konvensional, media baru dengan dasar open source. Sebagai media baru dengan basis open source, internet dapat digunakan dalam beragam bidang, seperti politik, bisnis, pemasaran, dan pemerintahan.

Era digital di Indonesia sendiri, tidak hanya membawa perubahan bagi orangorang yang berada di daerah perkotaan, yang memiliki mobilitas yang tinggi dan akses akan sumber daya yang memadai. Perubahan juga terjadi di daerah-daerah pedesaan, yang belum memiliki akses memadai dalam hal sumber daya.Sebagai salah satu contohnya adalah sebuah desa di provinsi Lombok yang bernama Desa Karang Bajo.

Desa Karang Bajo merupakan desa hasil pemekaran dari desa lain di Lombok Barat, yaitu Desa Bayan dan Desa Senaru. Desa Karang Bajo ini kemudian menerapkan pemerintahannya dengan memanfaatkan teknologi dan new media. Desa Karang Bajo membangun sebuah webstite yang dijadikan dan dikembangkan sebagai aplikasi sumber informasi desa. Website ini berisi seluruh berita, pengumuman, produk desa, peraturan, sampai dengan agenda yang dimiliki desa. Kemudian, pemerintahan desa bahkan menggunakan website ini menerbitkan seluruh laporan RKP (Rencan Kerja Pembangungan) Desa yang berisi anggaran dana desa. Pemerintahan desa di Karang Bajo bersifat transparan dan terbuka ke seluruh warga dan juga ke publik.

Tidak berhenti sampai disini, Desa Karang Bajo juga memiliki profile media sosial facebook, dimana semua kegiatan desa diupload kedalam halaman facebook dan para warga dapat memberikan komentar dan berinteraksi satu sama lain, baik antar warga maupun antara warga dengan aparat pemerintahan desa.

Keberhasilan Desa Karang Bajo dalam memanfaatkan teknologi media baru menjadikannya terkenal, bahkan kepala desanya Bapak Kertamalip dianggap sebagai kepala desa yang sangat inspiratif, walaupun Desa Karang Bajo sendiri merupakan sebuah desa kecil yang berada di kaki Gunung Rinjani, jauh dari pusat pemerintahan dan pusat kota Lombok. Sebagai kepala desa, Bapak Kertamalip mampu membangun sebuah desa online dan mendapatkan banyak penghargaan karenanya. Beberapa penghargaan yang pernah diraih Kertamalip adalah Penghargaan Pelita Nusantara yang diserahkan Wakil Presiden Boediono (2013), Kepala Desa Berprestasi Bidang Informasi Desa (2013) serta anugerah Kepala Desa Pelopor Good Governance dalam Pengelolaan Keuangan Desa (2015) (https://www.maxmanroe.com/kertamalipkepala-desa-online-yang-inspiratif-daridesa-karang-bajo-di-kaki-gunungrinjani.html).

Atas dasar keberhasilan dan pencapaian Desa Karang Bajo ini sebagai sebuah desa online, peneliti tertarik untuk melakukan penelitian disana untuk mengkaji pemanfaatan media baru yang diterapkan dalam sistem pemeritahan. Hal ini dikarenakan, walaupun masih sangat terbatas dan banyak bentuk komunikasi yang dilakukan bersifat satu arah, tetapi Desa Karang Bajo telah menerapkan sistem pemerintahan dengan cara $E$ Government atau electronic government. Secara sederhana Heeks, seperti yang dikutip dalam Hasibuan dan Santoso (2005: 42) mendefinisikan E-Government sebagai berikut: 'kegiatan yang dilakukan oleh pemerintah dengan menggunakan Teknologi Informasi (TI) untuk memberikan layanan kepada masyarakat'. Berdasarkan definisi tersebut dapat diketahui bahwa tujuan utama dari $E$ Government adalah untuk efisiensi dan kualitas layanan.

Hadirnya internet dan penerapan sistem E-Government di Desa Karang Bajo telah menunjukkan bahwa adanya media baru dalam bentuk internet ini telah 
membawa perubahan dalam hal sistem pemerintahan. Perubahan dalam sistem pemerintahan juga akan merubah masyarakat desa yang berada di dalamnya. Hal ini sejalan dengan konsep mediatiasi yang dapat diartikan sebagai konsep paling utama untuk memahami pentingnya media terhadap budaya dan masyarakat (Hjarvard, 2008: 106).

Definisi mengenai meditisasi tersebut menggambarkan mengenai pengaruh yang dimiliki media terhadap budaya dan masyarakat. Seperti, yang dijelaskan sebelumnya bahwa hadirnya new media ini merubahan banyak aspek dalam kehidupan manusia, salah satunya adalah cara manusia dalam berkomunikasi satu dengan lainnya.

Berdasarkan hal yang telah dijelaskan diatas, peneliti tertarik untuk meneliti mengenai penerapan dari EGovernment dan bagaimana mediatisasi ini merubah masyarakat dan budaya di Desa Karang Bajo, Lombok.Sebuah desa yang belum lama terbentuk tetapi telah menunjukkan keberanian dalam hal transparansi pemerintahan desa dan juga menunjukkan kemajuan di bidang penggunaan new media dan internet.

Oleh karena itu, konsep teori utama yang digunakan dalam penelitian adalah teori E-Government dari West (2005: 812); konsep mediatisai oleh Harvard (2008: 105-134); dan interaksi sosial. Kesemua konsep ini akan dibahas secara lebih mendalam berikut ini.

Tesu dan Daniela (2012:79) mendefinisikan E-Government sebagai suatu cara memanfaatkan alat dan sistem dalam tekonologi komunikasi informasi untuk menyediakan pelayanan publik yang lebih baik kepada masyarakat dan bisnis. E-Government yang efektif melibatkan serangkaian proses dan pemikiran ulang organisasi, serta perubahan perilaku sehingga pelayanan publik dapat disampaikan secara lebih efisien kepada orang yang membutuhkan. Jika diterapkan dengan baik, E-Government memungkinkan seluruh warga, perusahaan, dan organisasi untuk melaksanakan bisnis dengan pemerintahan secara lebih mudah, cepat, dan biaya yang lebih rendah.

West (2005: 8-12) menjelaskan bahwa terdapat empat tahap dari $E$ Government.Tetapi kategorisasi ini sendiri tidak berarti semua E-Government melalui semua tahapan ini dalam urutan linear. Terdapat beragam cara dimana $E$ Government telah berevolusi. Berdasarkan penelitian yang telah dilakukan, rangkaian ini hanya menjadi tindakan yang umum dilakukan dalam banyak yuridiksi. Berikut adalah ke empat tahapan tersebut: (1) Tahap Billboards, pada tahap ini website pemerintah sebagai sarana E-Government hanya digunakan sebagai billboard, atau dengan kata lain E-Government adalah mekanisme statik untuk menampilkan informasi; (2) Tahap The Partial ServiceDelivery, di mana pada tahap ini $E$ Government menggabungkan fitur pencarian informasi dan pelayanan parsial kedalam website. Pada tahap ini masyarakat dapat mengakses, memilih, dan mencari informasi; (3) Tahap portal dengan eksekusi penuh dan pelayanan terpadu, meliputi 'one-stop' portal pemerintahan dengan pelayanan online terpadu; (4) Demokrasi interaktif dengan pendekatan publik dan fitur peningkatan akuntabilitas, pada tahap ini website pemerintah menawarkan sebuah pilihan untuk dapat melakukan personalisasi website (misalnya penyesuaian atas kepentingan atau minat seseorang) dan mendorong teknologi (misalnya menyediakan email atau electronic subscription yang menyediakan perbaruan otomatis atas isu atau area yang diperhatikan orang tersebut).

Konsep mediatisasi menurut Stig Hjarvard (2008: 106) penting untuk mengerti pentingnya media bagi kebudayaan dan masyarakat. Istilah mediatisasi telah digunakan pada sejumlah konteks yang berhubungan dengan 
pengaruh media pada berbagai fenomena tapi baru sedikit usaha yang dilakukan untuk membuat konsep mediatisasi ini. Menurut Krotz dan Schulz dalam Hjarvard (2008: 106) baru belakangan ini saja peneliti media berusaha untuk mengembangkan konsep mediatisasi sebagai suatu proses sosial dan budaya.

Konsep mediatisasi pertama kali digunakan pada pengaruh media untuk komunikasi politik. Peneliti media dari Swedia, Kent Asp (1986) adalah orang yang pertama kali bicara mengenai mediatisasi pada kehidupan politik yang dia formulasikan sebagai 'a political system to a high degree is infuenced by and adjusted to the demands of the mass media in their coverage of politics". Menurut Asp salah satu bentuk mediatisasi ini adalah ketika seorang politikus membungkus pernyataan politiknya untuk konsumsi publik dengan cara membuatnya menjadi personal dan mempolarisasi sebuah isu sehingga pesan tersebut akan mendapat perhatian dari media lebih baik lagi (Hjarvard, 2008: 106).

Teori mediatisasi harus mampu untuk menjelaskan secara keseluruhan perkembangan trend dalam masyarakat dalam konteks yang berbeda, melakukan analisa yang konkrit dan menunjukan impak dari media pada berbagai institusi dan kegiatan manusia (Hjarvard, 2008: 113). Dengan menggunakan teori mediatisasi maka peneliti berusaha menjelaskan bagaimana arti media onlineyang diciptakan oleh Pemerintah Desa Karang Bajo untuk masyarakat Desa Karang Bajo, Kecamatan Bayan, kabupaten Lombok Utara.

Alo Liliweri (2005: 127) secara sederhana mendefinisikan interaksi sosial sebagai suatu proses yang dilakukan oleh setiap orang ketika dia bertindak dalam sebuah relasi dengan orang lain. Interaksi sosial merupakan sebuah proses yang kompleks, yang dilalui oleh setiap orang ketika mengorganisasi dan menginterpretasikan persepsi tentang orang lain dalam situasi dimana dirinya ikut berada.

Ada dua syarat utama yang harus dipenuhi dalam melakukan interaksi sosial, yaitu: adanya kontak sosial dan adanya komunikasi (Burhan Bungin, 2006: 55). Kontak baru terjadi ketika ada hubungan fisik. Tetapi dalam konteks interaksi sosial antara manusia, kontak tidak perlu berarti adanya hubungan fisik, karena manusia dapat melakukan kontak tanpa harus menyentuh. Misalnya adalah dengan menggunakan teknologi komunikasi yang ada seperti telepon atau email untuk melakukan kontak dengan manusia lainnya. Syarat kedua dalam interaksi sosial adalah komunikasi. Arti terpenting dalam komunikasi adalah bahwa seseorang memberikan tafsiran pada perilaku orang lain. Orang yang bersangkutan kemudian memberikan reaksi. Dengan adanya komunikasi tersebut dapat membantu manusia, baik orang perorangan maupun kelompok untuk meyampaikan perasaan yang dimilikinya terhadap orang lain. Komunikasi juga membantu manusia untuk mengetahui apa yang ada dalam pikiran dan perasaan seseorang mengenai sesuatu atau seseorang. Berdasarkan komunikasi inilah manusia menentukan respon atau reaksi apa yang akan diberikan.

Berkembangnya teknologi komunikasi dan informasi juga membawa perubahan dalam interaksi yang terjadi antar manusia. Kontak dan komunikasi yang dibutuhkan sebagai syarat dalam interaksi dapat dilakukan melalui teknologi komunikasi komputer. Wood \& Smith (2005: xiv) menyatakan bahwa konteks komunikasi dalam medium komputer berbeda dengan komunikasi dalam bentuk lainnya, terdapat pengalaman interaksi yang berbeda melalui komunikasi online.

Komunikasi online erat dikaitkan dengan komputer dan internet. Lebih lanjut, Wood \& Smith (2005: xv) menjelaskan bahwa saluran komunikasi yang biasa digunakan dalam komunikasi 
online adalah melalui e-mail, bulletin borad system, dan world wide web (WWW). Melalui komunikasi online inilah tercipta konsep cyberspace yang menjadi tempat terjadinya interaksi secara online.

\section{Metodologi}

Pendekatan yang digunakan dalam penelitian ini adalah pendekatan kualitatif. Pendekatan kualitatif ini dipilih karena peneliti menganggap bahwa pendekatan kualitatif merupakan pendekatan paling sesuai untuk menggambarkan tujuan penelitian ini, yaitu untuk mengetahui penerapan E-Government, tujuannya, dan faktor pendukung dan penghambat dari penerapannya di Desa Karang Bajo. Serta bagaimana penerapan E-Government ini yang merupakan bagian dari meditisasi merubah interaksi sosial masyarakat di desa tersebut.

Selain itu, pendekatan yang digunakan adalah menggunakan pendekatan kualitatif studi kasus. Robert E. Stake seperti dikutip dalam Denzin dan Lincoln (1994: 236) menuliskan bahwa studi kasus bukannya suatu pilihan methodologikal tetapi merupakan sebuah pilihan atas objek yang ingin dipelajari.Sebagai sebuah bentuk penelitian, studi kasus di definisikan oleh ketertarikan individu terhadap kasus tersebut, dan bukannya oleh metode penelitian yang digunakan.Penelitian ini sendiri merupakan penelitian studi kasus menggunakan model deskriptif.Model deskriptif dipilih karena penelitian ini merupakan penelitian awal atau pembuka dari rangkaian penelitian di Desa Karang Bajo. Data dari penelitian akan menjadi dasar untuk penelitian berikutnya yang akan menggali secara lebih mendalam permasalahan yang terdapar di Desa Karang Bajo.

Objek penelitian ini adalah aparat pemerintahan desa Karang Bajo di Lombok, Nusa Tenggara Barat. Narasumber dalam penelitian ini adalah Bapak Kertamalip yang merupakan Kepala
Desa Karang Bajo, Ibu Suriatni yang merupakan Sekretaris Desa Karang Bajo, dan Bapak Iramawan yang merupakan salah satu Kepala Dusun di Desa Karang Bajo.

Data dalam penelitian ini terdiri dari data primer dan juga data sekunder.Data primer dalam penelititan ini diperoleh melalui wawancara mendalam dengan narasumber. Kemudian data penelitian juga diperoleh dengan cara observasi dan pengumpulan studi pustaka yang relevan dalam penelitian ini. Studi pustaka diperoleh melalui berbagai sumber, mulai dari sumber buku sampai dengan sumber online.

\section{Hasil dan Pembahasan}

Desa Karang Bajo, Kecamatan Bayan merupakan pemekaran dari Desa Bayan dan Desa Senaru pada tanggal 11 Oktober 2004 sesuai dengan Peraturan Bupati Lombok Barat nomor 9 Tahun 2004 tentang Pengesahan Pendirian Desa Perisiapan Karang Bajo di Kecamatan Bayan, Kabupaten Lombok Barat, Provinsi Nusa Tenggara Barat. Desa Karang Bajo didefinitifkan pada tanggal 30 Desember 2005 sesuai Peraturan Bupati Lombok Barat nomor 17 tahun 2005 tentang Peningkatan Desa Persiapan Karang Bajo, Kecamatan Bayan menjadi desa difinitif.

Desa Karang Bajo melakukan pemilihan pertama pada tanggal 11 Februari 2007 untuk masa jabatan 20072013 dengan 2 orang calon yaitu Mistradi dan Kertamalip, dan yang terpilih pada saat itu adalah Kertamalip sehingga pelantikan kepala desa terpilih tanggal 5 Maret 2007 dikuatkan dengan Surat Keputusan Bupati Lombok Barat Nomor 72/17/PEM/2007 tentang Pengesahan Pengangkatan Kepala Desa terpilih di Desa Karang Bajo, Kecamatan Bayan, tanggal 2 Maret 2007.

Desa Karang Bajo melakukan pemilihan kedua pada Desember 2012 untuk masa jabatan tahun 2013-2019 dengan 2 orang calon yaitu Supardi dan 
Kertamalip dan yang terpilih adalah Kertamalip sehingga pelantikan kepala desa terpilih tanggal 10 Januari 2013 dikuatkan dengan Surat Keputusan Bupati Lombok Utara tentang Pengesahan Pengangkatan Kepala Desa terpilih di Desa Karang Bajo, Kecamatan Bayan, tanggal 1 Januari 2013.

Berikutnya akan menjelaskan tentang hasil dan temuan dalam penelitian ini, kemudian bagaimana hasil temuan ini dianalisis berdasarkan teori yang telak dikemukakan pada bab landasan teori. Sebelum penjelasan dan pembahasan lebih lanjut, data hasil dan temua dalam penelitian ini diperoleh melalui hasil wawancara dengan narasumber, observasi dan bahan pustaka dari berbagai sumber. Fokus utama dari penelitian ini adalah penerapan E-Government di Desa Karang Bajo dalam kaitannya dengan mediatisasi dan perubahan interaksi sosial di masyarakatnya.

West (2005: 8-12) menjelaskan bahwa terdapat empat tahap dari $E$ Government. Tetapi kategorisasi ini sendiri tidak berarti semua E-Government melalui semua tahapan ini dalam urutan linear. Terdapat beragam cara di mana $E$ Government telah berevolusi. Berikut adalah ke empat tahapan tersebut: (1) Tahap Billboards; (2) Tahap The Partial Service-Delivery; (3) Tahap portal dengan eksekusi penuh dan pelayanan terpadu; (4) Demokrasi interaktif dengan pendekatan publik dan fitur peningkatan akuntabilitas. Berdasarkan tahapan yang dikemukan oleh West (2005), maka E-Government yang diterapkan oleh Desa Karang Bajo masih berada pada tahap pertama atau tahap billboards. Hal ini dapat dilihat melalui website Desa Karang Bajo yang hanya menampilkan informasi, seperti pengumuman laporan dan publikasi. Sistem E-Government masih bersifat satu arah dan tidak memungkinkan untuk dilakukannya komunikasi dua arah antara masyarakat dan aparat pemerintahan.

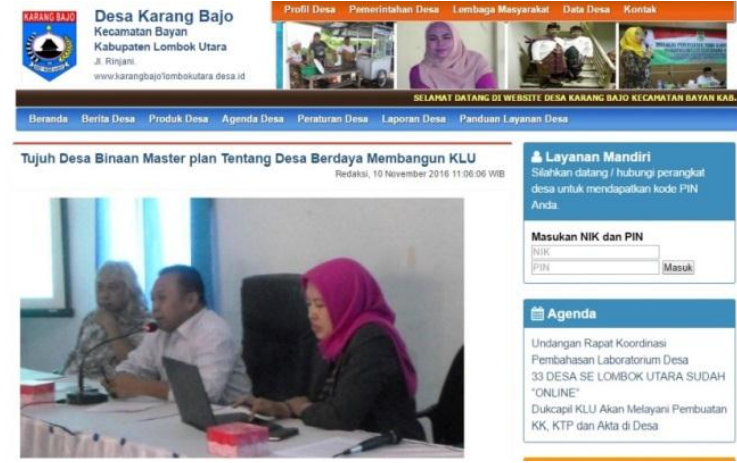

Gambar 1. Website Desa Karang Bajo

Selama penelitian ini berlangsung, peneliti melakukan wawancara dengan beberapa aparat pemerintahan, yaitu kepada desa Bapak Kertamalip (K), sekretaris desa Ibu Suriatni (S), dan salah satu kadus Bapak Iramawan (I). Berdasarkan hasil wawancara dengan Bapak K diketahui bahwa awal tujuan dibuat dan diterapkannya sistem EGovernment adalah karena adanya Undang-Undang No 6 Tahun 2014, khususnya pasal 86 tentang Sistem Informasi Pembangunan Desa dan Pembangunan Kawasan Perdesaan. Berikut adalah isi dalam UU No.6 Tahun 2014 Pasal 86.

(1) Desa berhak mendapatkan akses informasi melalui sistem informasi Desa yang dikembangkan oleh Pemerintah Daerah Kabupaten/Kota.

(2) Pemerintah dan Pemerintah Daerah wajib mengembangkan sistem informasi Desa dan pembangunan Kawasan Perdesaan.

(3) Sistem informasi Desa sebagaimana dimaksud pada ayat (2) meliputi fasilitas perangkat keras dan perangkat lunak, jaringan, serta sumber daya manusia.

Atas dasar adanya UU No. 6 tahun 2016 ini pemerintahan Desa Karang Bajo membangun Sistem Informasi Desa dalam bentuk website untuk penerapan EGovernment. Bapak K menyatakan bahwa dari website tersebut dibuat juga untuk dapat memberikan informasi kepada masyarakat didalam dan diluar Desa Karang Bajo. Website tersebut juga terbentuk dikarenakan adanya dana desa yang disesuaikan dengan UU No.6 Tahun 
2014 Pasal 114, yang diterima dari pemerintah. Adanya pemberian dana desa sehingga pemerintahan desa harus memberikan laporan hasil penganggaran lewat website, dengan cara tersebut pemerintah pusat dan daerah dapat memantau anggaran yang dilakukan untuk pembangunan prasarana dan sarana desa tersebut.

Bila dilihat dari sejarahnya, bahkan sebelum adanya UU No.6 Tahun 2014 ini Desa Karang Bajo telah memiliki sistem informasi untuk desa dalam bentuk radio komunitas pada tahun 2002, Radio Komunitas Primadona.Radio komunitas ini berfungsu untuk memberikan informasi seputar desa dan dapat di dengar oleh seluruh masyarakat desa.Tetapi sejak tahun 2010 radio komunitas ini kurang diminati, oleh karena itu kemudian dibuat juga blog, desakarangbajo.blogspot.com dan juga media sosial Facebook. Hanya saja nama akun Facebook yang jadi sumber informasi ini masih atas nama pribadi milik Bapak $\mathrm{K}$, yaitu akun Facebook Bang Ardes.

Sejak diterapkannya sistem EGovernment melalui website ini, setiap berita yang diupload ke dalam website juga diupload ke dalam akun Facebook Bang Ardes. Hal ini dilakukan untuk mempermudah warga untuk mendapatkan informasi mengenai desa.Sebagian besar warga Desa Karang Bajo masih berada didalam kemiskinan sehingga tingkat pendidikan yang dimiliki tidak terlalu tinggi, kemudian akses yang dimiliki terhadap teknologi juga masih terbilang rendah. Hal ini menjadikan sistem pemerintahan melalui E-Government terhambat.

Berdasarkan hasil wawancara dengan Bapak I dan Ibu S diketahui bahwa biasanya setiap keluarga di Desa Karang Bajo hanya memiliki satu buah handphone yang dipegang oleh kepala keluarga (ayah/suami). Akses terhadap internetpun terbatas pada pulsa yang dimiliki untuk membeli paket data.Pada umumnya handphone lebih dimanfaatkan sebagai alat untuk melakukan telepon atau SMS daripada untuk browsing internet atau membuka website desa. Kegiatan warga yang melibatkan internet masih sangat terbatas pada ketertarikan hanya untuk membuka media sosial Facebook.

Wawancara dengan Ibu S menunjukkan bahwa walaupun dirinya menjadi salah satu perangkat desa, tapi dirinya tidak paham dengan website ataupun Sistem Informasi Desa atau $E$ Government. Ibu $\mathrm{S}$ juga menyebutkan bahwa sebatas yang dipahaminya website desa hanya ditujukan bagi para perangkat desa. Hasil wawancara juga menunjukkan bahwa Ibu $\mathrm{S}$ menggunakan internet hanya untuk membuka email, karena sebagai seorang Pegawai Negeri Sipil (PNS) dirinya memiliki keharusan untuk memiliki email. Dirinya memiliki handphone hanya untuk melakukan SMS dan telepon, bahkan Ibu S tidak memiliki akun Facebook. Ibu S berpendapat bahwa seorang perempuan yang memiliki akun Facebook, hanyalah perempuan yang kurang pekerjaan.

Anggapan bahwa perempuan juga tidak seharusnya memiliki akun Facebook juga sesuai dengan hasil wawancara dengan Bapak I. Bapak I mengatakan bahwa mayoritas yang memiliki akun Facebook di Desa Karang Bajo hanyalah kaum laki-laki. Perempuan di Desa Karang Bajo hanya paham mengenai hal bekerja di sawah. Pandangan ini menjadikan perempuan semakin terbatas aksesnya terhadap teknologi dan internet, karenanya mengenai sistem E-Government sejauh ini tidak dipahami sama sekali oleh kaum perempuan.

Faktor penghambat dalam sistem $E$ Government juga masih terlihat dalam visi dan misi yang dimiliki oleh Desa Karang Bajo. Visi dan misi masih berfokus pada hal-hal mendasar, seperti terwujudnya masyarakat Desa Karang Bajo yang sehat, bersih, indah, aman dan sejahtera; dan misi AKINO (Angka Kematian Ibu 
Melahirkan Nol). Berdasarkan visi dan misi ini, peran E-Government didalamnya belum dibutuhkan. E-Government ada hanya sebatas pada keharusan yang diwajibkan oleh pemerintah atas dasar UU No. 6 tahun 2014.

Walaupun penerapan E-Government di Desa Karang Bajo masih sangat minim dan memiliki banyak faktor penghambat, tetapi kemungkinan untuk terus dikembangkan yang menjadi faktor pendukung masih ada. Pada pembahasan sebelumnya diketahui bahwa minat masyarakat Desa Karang Bajo terhadap internet masih sebatas pada penggunaan media sosial Facebook. Atas dasar ini, Bapak K juga mem-posting setiap berita dalam website ke dalam akun Facebook pribadinya, dengan harapan agar masyarakat desa yang melihatnya mengklik link tersebut dan secara otomatis akan membuka website desa. Walaupun, keefektifan dari hal ini masih belum dapat dibuktikan tetapi hal ini dapat dikatakan sebagai langkah awal untuk membangun minat dan pengetahuan masyarakat atas adanya E-Government di Desa Karang Bajo.

Adanya dana desa yang didapatkan dari pemerintah dapat digunakan untuk membangun sarana dan prasaran yang lebih memadai untuk memudahkan masyarakat Desa Karang Bajo untuk mendapatkan akses terhadap internet dan juga teknologi. Kemudian adanya perangkat desa dengan jabatan Operator (SID) yang dijabat oleh Bapak Hamzamwadi. Saat ini tugas utama Bapak Hamzamwadi adalah membuat database warga Desa Karang Bajo, sehingga masyarakat yang butuh pelayanan membuat surat keterangan butuh hanya 2 menit untuk menyelesaikannya, karena datanya sudah ada.

Berdasarkan hasil wawancara dengan Bapak K, E-Government mulai diterapkan sejak tahun 2015. Hal ini dibarengi dengan kondisi masyarakat yang pada umumnya telah memiliki handphone.
Kondisi ini dapat dimanfaatkan untuk meningkatkan kesadaran masyarakat untuk membuka website desa sebagai bentuk pelaksanaan E-Government di Desa Karang Bajo. Diharapkan dengan adanya faktor-faktor pendukung ini penerapan $E$ Government dapat semakin ditingkatkan dan berkembang tahapannya menjadi ke tahap berikutnya, sesuai dengan tahapan yang diberikan oleh West (2005: 8-12).

Sejalan dengan penerapan EGovernment dan kondisi trend masyarakat akan media online, khususnya media sosial Facebook. Peneliti juga mendapatkan temuan bahwa interaksi diantara masyarakat desa mulai mengalami perubahan. Perubahan ini merupakan akibat dari adanya mediatisai. Hjarvard (2008: 113) mengatakan bahwa teori mediatisasi harus mampu untuk menjelaskan secara keseluruhan perkembangan trend dalam masyarakat dalam konteks yang berbeda, melakukan analisa yang konkrit dan menunjukan impak dari media pada berbagai institusi dan kegiatan manusia.

Winfried Schulz dalam Hjarvard (2008: 109-110), mengidentifikasikan empat bentuk proses media dalam merubah komunikasi dan interaksi manusia. Pertama, media online dapat meningkatkan kemampuan berkomunikasi masyarakat bila dilihat dari sisi waktu dan jarak. Kedua, media internet dapat mengganti kegiatan sosial yang biasa dilakukan masyarakat secara tatap muka. Ketiga, media online dapat menjadi perantara dari gabungan kegiatan; kegiatan tatap muka dikombinasikan melalui media. Terakhir masyarakat menyesuaikan tingkah laku untuk mengakomodasikan dengan bentuk media.

Bila dikaitkan antara proses dari Winfried Schulz dengan hasil penelitian yang ditemukan di lapangan, maka dapat dikatakan ke empat tahapan proses tersebut terjadi di Desa Karang Bajo. Hanya saja media online yang lebih berperan dalam terciptanya proses tersebut 
adalah media sosial Facebook, bukanya media online website sebagai bentuk penerapan dari E-Government di Desa Karang Bajo.

Konsep mediatisasi dalam merubah komunikasi dan interaksi manusia di Desa Karang Bajo menunjukkan bahwa berkembangnya teknologi komunikasi dan informasi juga membawa perubahan dalam interaksi yang terjadi antar manusia. Bungin (2006: 55) menyebutkan bahwa kontak dan komunikasi dibutuhkan sebagai syarat dalam interaksi sosial, dan hal ini dapat dilakukan melalui teknologi komunikasi komputer.

Wood \& Smith (2005: xiv-xv) menyatakan bahwa konteks komunikasi dalam medium komputer berbeda dengan komunikasi dalam bentuk lainnya, terdapat pengalaman interaksi yang berbeda melalui komunikasi online. Komunikasi online erat dikaitkan dengan komputer dan internet. Dikatakan berbeda karena warga Desa Karang Bajo tidak lagi harus melakukan komunikasi dan interaksi secara langsung atau tatap muka, tetapi komunikasi dan interaksi dapat dilakukan secara online di cyberspace. Warga desapun tidak lagi membutuhkan banyak waktu untuk melakukan interaksi satu sama lain.

Kemudian selain temuan dan pembahasan yang telah dijelaskan diatas, peneliti menemukan beberapa temuan lain yang menarik terkait dengan penelitian ini. Pertama terkait dengan masalah gender, melalui penelitian ini diketahui bahwa perempuan sangat terbatas dalam memiliki akses terhadap teknologi dan juga internet. Hal ini dikarenakan adanya anggapan bahwa perempuan seharusnya berfokus pada urusan rumah tangga bukan pada gadgets atau juga media sosial. Oleh karenanya perempuan Desa Karang Bajo sangat minim pengetahuannya akan teknologi. Istri Bapak $\mathrm{K}$ yang merupakan Kades bahkan tidak bisa memakai handphone dan tidak paham apa itu Facebook. Pandangan juga ditegaskan oleh
Ibu S yang mengatakan bahwa perempuan yang memiliki akun Facebook hanya perempuang yang kurang pekerjaan. Dalam wawancara dengan Bapak K diketahui bahwa perempuan jarang yang memiliki akun Facebook karena bila perempuan yang sudah menjadi istri ini terlalu aktif di Facebook akan menimbulkan kecemburuan sang suami, tetapi hal sebaliknya tidak terjadi.

Kedua, terkait dengan penerapan $E$ Government, hanya Bapak K yang dapat mengupload berita dan laporan ke dalam website. Hal ini dilakukan dengan alasan agar berita yang masuk ke dalam website dapat dikontrol dan dijaga kualitasnya atau dengan kata lain Bapak $\mathrm{K}$ menjadi gatekeeper. Tidak ada satu orangpun yang menjadi perangkat desa dapat menggantikan peran Bapak K ini.Seluruh password dan id untuk masuk ke dalam website administrator hanya diketahui oleh Bapak K.

\section{Penutup}

Berdasarkan hasil dan pembahasan pada bab sebelumnya dan rumusan masalah dalam penelitian maka terdapat 4 hal utama yang dapat disimpulkan dalam penelitian ini, yaitu:

Pertama, penerapan E-Government yang diterapkan oleh Desa Karang Bajo masih berada pada tahap pertama menurut West (2005) atau tahap billboards. Hal ini dapat dilihat melalui website Desa Karang Bajo yang hanya menampilkan informasi, seperti pengumuman laporan dan publikasi. Sistem E-Government masih bersifat satu arah dan tidak memungkinkan untuk dilakukannya komunikasi dua arah antara masyarakat dan aparat pemerintahan.

Kedua, tujuan utama dari diterapankan sistem E-Government di Desa Karang Bajo adalah karenanya adanya UU No.6 Tahun 2014 yang menyatakan bahwa setiap desa harus memiliki sistem informasi desa, dan karenanya mendapatkan dana desa sebagai 
bantuan dari pemerintah pusat yang harus dilaporkan secara online.

Ketiga, adalah faktor penghambat dan pendukung dari pelaksanaan $E$ Government. Faktor penghambat terlihat dari masih banyaknya warga yang hidup dalam kemiskinan sehingga akses dimiliki terhadap teknologi dan internet masih sangat terbatas; kurangnya minat masyarakat terhadap E-Government; visi dan misi desa yang masih jauh kaitannya dengan E-Government. Untuk faktor pendukung dapat dilihat dari adanya dana desa yang berasal dari pemerintah pusat yang dapat digunakan untuk membangun infrastruktur; solusi dari Bapak $\mathrm{K}$ yang juga memposting berita website ke dalam akun Facebook milikinya; kondisi trend di masyarakat yang mulai tertarik pada teknologi dan sosial media dapat dimanfaatkan.

Keempat, konsep mediatisasi merubah komunikasi dan interaksi manusia di Desa Karang Bajo. Konsep mediatisasi yang dimaksud disini adalah bukan merujuk pada konsep $E$ Government melainkan pada hadirnya media sosial facebook dikalangan masyarakat Desa Karang Bajo.

\section{Daftar Pustaka}

Bungin, B. (2006). Sosiologi Komunikasi. Jakarta: Prenada Media Group.

Denzin, N. K., \& Lincoln, Y. S. (1994). Handbook of qualitative research. London: SAGE Publisher.

Liliweri, A. (2005). Prasangka \& Konflik: Komunikasi Lintas Budaya Masyarakat Multikultur. Yogyakarta: LKiS Yogyakarta.
West, D. M. (2005). Digital Government: Technology and Public Sector Performance. United Kingdom: Princeton University Press.

Wood, A. F., \& Smith, M. J. (2005). Online Communication: Linking Technology, Identity, and Culture $\left(2^{\text {nd }}\right.$ Ed.). Mahwah, New Jersey: Lawrence Erlbaum Associates.

Wynants, M. \& Cornelis, J. (2005). How Open Is the Future?: Economic, Social \& Cultural Scenarios Inspired by Free \& Open-Source Software. USA: Crosstalks.

Hasibuan, Z. A. \& Santoso, H. B. (2005). Standardisasi Aplikasi EGovernment Untuk Instansi Pemerintah. Prosiding Konferensi Nasional Teknologi Informasi dan Komunikasi Indonesia, 42-48.

Hjarvard, S. (2008). The Mediatization Of Society: A Theory Of The Media As Agents Of Social And Cultural Change. Nordicom Review, 29 (2), 105-134.

Tesu \& Daniela, M. (2012). Developing EGovernment for Better Public Services Within European Union. Theoretical and Empirical Researches in Urban Management, 7 (2).

Kertamalip. (2017). Kepala Desa 'Online' yang Inspiratif dari Desa Karang Bajo di Kaki Gunung Rinjani. Diakses pada 14 Juli 2017, dari https://www.maxmanroe.com/kertam alip-kepala-desa-online-yanginspiratif-dari-desa-karang-bajo-dikaki-gunung-rinjani.html 